\title{
Reconciling geodetic and geological rates of vertical crustal motion in intraplate regions
}

\author{
A. Demoulin* \\ Research Associate NFSR, Department of Physical Geography and Quaternary, University of Liège, Sart Tilman B11, 4000 Liège, \\ Belgium
}

Received 29 August 2003; received in revised form 27 October 2003; accepted 29 January 2004

\begin{abstract}
Tectonic motion rates of individual faults and regional deformation in an intraplate setting are estimated, based on the analysis of ten yearly surveys of a regional levelling network in NE Ardenne (W Europe). Owing to the frequency and number of measurement epochs, much greater than in classical comparisons of general surveys, the tectonic and near-surface components of ground motion are clearly separated. The marked temporal variability in ground motion strongly depends on the amount of precipitation fallen during the six months preceding each survey and the subsequent drying off of the subsoil at the time of the surveys. Moreover, the ground response to this influence varies from place to place, leading to high differential movements at the local scale. Taking into account the percentage of surveyed faults which moved tectonically during the time of the study, I calculate fault motion rates of $0.06-0.09 \mathrm{~mm} /$ $\mathrm{yr}$, similar to geological rates. Moreover, the data indicate that one way for intraplate normal faults to accommodate tectonic strain aseismically is intermittent fault creep, with short episodes of a few mm displacement separated by many year-long time intervals of fault quiescence. A flexural deformation shows the superposition of a tilt event on a trend corresponding to a tilt rate of $0.16 \mu \mathrm{rad} / \mathrm{yr}$ for a $2.8-\mathrm{km}$-long segment.
\end{abstract}

(C) 2004 Elsevier B.V. All rights reserved.

Keywords: crustal motion; intraplate; levelling; hydrological factor; geodetic rate; fault creep

\section{Introduction}

There is a persisting contradiction between the high rates of vertical motion inferred from geodetic data $(0.5-5 \mathrm{~mm} / \mathrm{yr})$ [1-7] and one order of magnitude lower long-term rates deduced from

* Tel.: +32-4-366-5660; Fax: +32-4-366-5722.

E-mail address: ademoulin@ulg.ac.be (A. Demoulin). geological observations [8-11] for individual structures and regional deformation in intraplate settings (Table 1). This is mainly due to the very low actual rates of crustal motion in these regions, implying that long periods of observation are needed for tectonic displacements to exceed the measurement noise and that many non-tectonic causes of such movements have also to be considered. However, the high geodetic rate estimates have contributed to the assumption that many areas currently experience increased tectonic activity $[12,13]$ or that the contribution of transient 
Table 1

Geodetic vs. geological rate estimates of vertical ground motion in intraplate settings

\begin{tabular}{llll}
\hline Area & $\begin{array}{l}\text { Geodetic } \\
(\mathrm{mm} / \mathrm{yr})\end{array}$ & $\begin{array}{l}\text { Geological } \\
(1-0 \mathrm{Ma}), \mathrm{mm} / \mathrm{yr}\end{array}$ & References \\
\hline Regional motion & 1.6 & 0.25 & {$[1] \leftrightarrow[16]$} \\
Eifel (D) & 0.8 & 0.06 & {$[12] \leftrightarrow[35]$} \\
S Limburg (NL) & $>1.0$ & $\sim 0.1$ & {$[4] \leftrightarrow[36]$} \\
Upper Rhine graben (F) & 1.0 & & {$[5]$} \\
W Brittany (F) & 0.8 & $\sim 0.1$ & {$[37] \leftrightarrow[38]$} \\
NE Spain (SP) & 1.3 & $0.07-0.1$ & {$[35] \leftrightarrow[39]$} \\
Ardenne (B) & 1.5 & 0.2 & {$[11]$} \\
Fault motion & & $0.08-0.15$ & {$[40] \leftrightarrow[41]$} \\
Roer graben (NL) & $0.9-2.0$ & & \\
Upper Rhine graben (CH) & & & {$[36]$} \\
E Betics (SP) &
\end{tabular}

seismotectonic processes is recorded at the geodetic timescale [14].

From 1993 to 2002, we carried out repeated high precision levellings across the northern margin of the uplifted Ardenne massif in the extensional setting of the Lower Rhine Embayment (W Europe). The first aim of the study was to separate the tectonic and near-surface components of the recorded vertical ground motions. Among near-surface causes of movement, particular attention has been paid to the influence of water in the soil and subsoil. The second and main objective lay in identifying and characterising possible individual fault motions, especially getting a closer look at their temporal evolution. More generally, I attempted to estimate average fault motion and regional deformation rates for the study area, to be compared with figures deduced from geological observations. Both objectives required that the levelled network be surveyed as many times as possible. We thus conducted ten levelling campaigns at $1-y r$ intervals.

\section{Geological setting}

The study area extends across the NE margin of the Ardenne in E Belgium (Fig. 1). The Ardenne is a Palaeozoic massif located to the west of the Lower Rhine segment of the European Cenozoic Rift System. The levelling network is situated $\sim 20 \mathrm{~km} \mathrm{SW}$ from the major bounding faults of this graben. It extends on the northern flank of the Cambrian Stavelot massif, where the Variscan fold-and-thrust belt has been superposed on structures inherited from the Caledonian orogeny, resulting in a structurally complex basement wherein longitudinal ENE-WSW folds and thrust faults are cut by numerous NW-SE to NNW-SSE striking normal faults.

The region has uplifted between 400 and $500 \mathrm{~m}$ since the Oligocene chiefly in response to far-field stresses (Alpine push, N Atlantic oceanic expansion) and possibly also as a consequence of mantle upwelling beneath the nearby Eifel [15]. The uplift rate sharply increased from the Pliocene, culminating at a mean $0.1 \mathrm{~mm} / \mathrm{yr}$ in the early and middle Pleistocene. Studies of Quaternary river incision suggest that uplift rates up to $\sim 0.5$ $\mathrm{mm} / \mathrm{yr}$ could be reached in NE Ardenne between 800 and $400 \mathrm{ka}$ but that tectonic quiescence prevailed in recent times [16-18].

Superimposed on this epeirogenic upheaval, several NNW-SSE normal faults cutting the Stavelot massif and its northern foreland have been reactivated in close relation with the opening of the Lower Rhine rift segment since the upper Oligocene. The Lower Rhine graben and its western shoulder, including the NE Ardenne, are currently characterised by weak to moderate seismicity [19]. One of the most violent historical earthquakes having ever struck NW Europe, the Verviers earthquake of 1692, occurred somewhere in close vicinity to our study area [20]. 

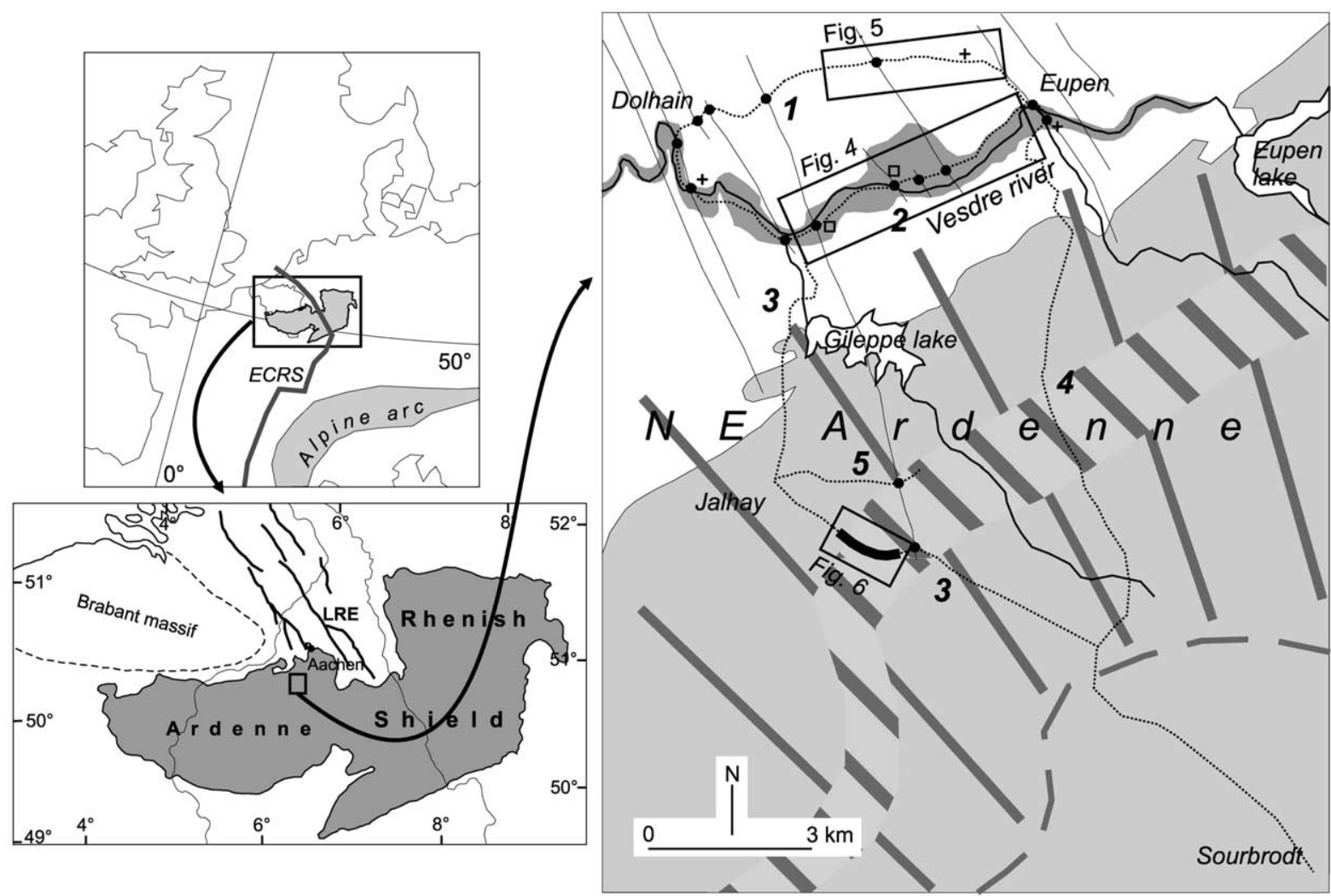

Fig. 1. Sketch map of the levelled network (dotted lines) in NE Ardenne. Black dots localise the places where the levelling lines cross potentially moving faults. Actually recorded fault motions are either of tectonic origin (crosses, black bold line) or dryingoff-dependent (open squares). Light grey: Cambrian core of the NE Ardenne massif. Dark grey: Vesdre valley (alluvial plain+low terraces). Narrow grey hatching localises the flexure developed along the northern slope (broader hatching) of the Ardenne massif. Insets: ECRS, European Cenozoic Rift System; LRE, Lower Rhine Embayment.

\section{The data}

Ten yearly surveys of the 48-km-long levelling network (58 sections) are available for the 19932002 period. The surveyed area includes several normal faults active during the Quaternary and the flexured border of the massif (Fig. 1). The majority of the benchmarks belong to the firstorder levelling network of the Belgian National Geographical Institute, except along the eastern half of levelling line 2 (Fig. 1) where we installed new marks. Most of the benchmarks we used are set either in Palaeozoic rock outcrops or at the base of $\geq 40$-year-old stone or brick buildings generally with foundations $2-2.5 \mathrm{~m}$ deep. Local geological conditions are of three main types. Most geodetic monuments are built on fresh $\mathrm{Pa}$ - laeozoic rocks. In the Vesdre valley, they are founded in alluvial plain or low terrace deposits. In the south of the network, on the top of the massif, they lie on a weathered Palaeozoic basement or Cretaceous clay-with-flints.

We used Leica NA-3000 levels and 3-m-long code bar invar rods (the same pairs of rods from 1993 to 2002). Data acquisition met all requirements of Belgian first-order levelling, corresponding to the recommendations of the International Association of Geodesy. The data have been corrected for the thermal expansion of the rods. Height-dependent systematic errors due to unequal atmospheric refraction or progressive damaging of the rod invar tapes were tracked by searching for correlation between section slope and tilt [21]. Another systematic error in the 
1994 measurements was suggested by the mirror images yielded by the successive height change profiles of 1993-1994 and 1994-1995 for the apparently tilted levelling line 1 (Fig. 1), and confirmed by the marked trend displayed by the section misclosures along the line in 1994 [22]. This error has been removed by subtracting the apparent tilt of $0.81 \mu \mathrm{rad}$ from the 1994-1995 profile.

After data correction, we observed several marked local height changes in yearly comparisons, especially ground motion discontinuities between segments of otherwise homogeneous behaviour and tilting of segments of the levelling lines. The highest variation of the height difference between nearby benchmarks recorded by successive surveys amounted to $16 \mathrm{~mm}$. This is far greater than the measurement standard error of $1.16 \mathrm{~L}^{1 / 2}$ $\mathrm{mm}$ obtained for the worst survey comparison,
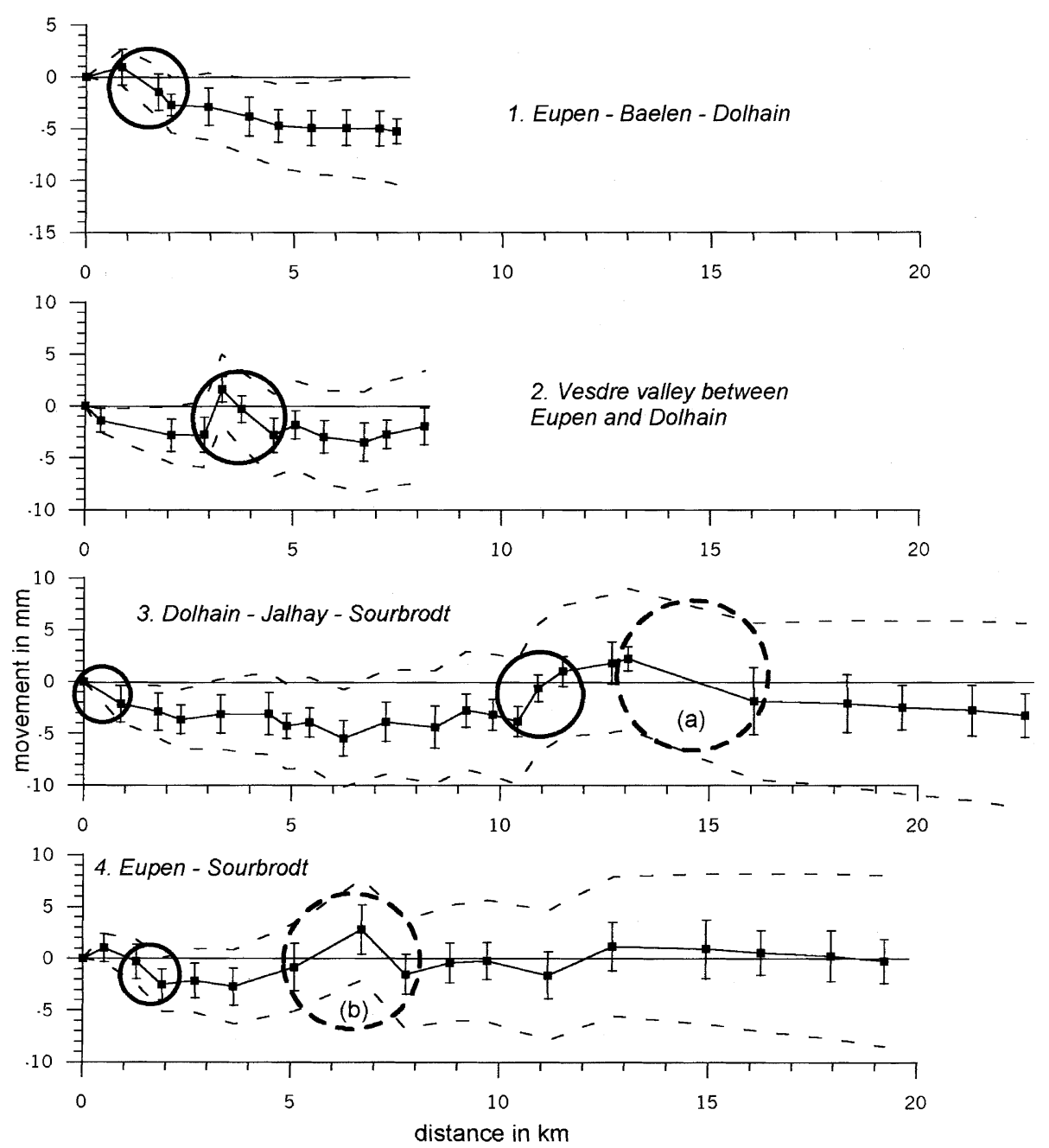

Fig. 2. Some examples of vertical ground motion between two surveys (1995 and 2001) carried out after winter seasons with similar '6 months' Rainfall Function (RF) values. The line numbers refer to the numbers indicated in Fig. 1. The dashed lines encompass the $2 \sigma$ areas propagating with $\mathrm{L}^{1 / 2}$ for the whole lines with respect to their starting point. The error bars associated with the data points denote the $2 \sigma$ uncertainty of each individual section. Open circles locate the few significant motion discontinuities in these profiles. The anomalies marked by circles in dashed lines are not considered because either the length of the section (a) or the isolated position of the displaced benchmark (b) makes the motion less reliable. 
which implies that every sharp discontinuity of motion higher than $\sim 2.3 \mathrm{~mm}$ between benchmarks $1 \mathrm{~km}$ apart indicates a true ground displacement at the $95 \%$ confidence level. As for the yearly tilt of $\sim 5$-km-long segments involving 6-7 benchmarks, values of up to $2 \mu \mathrm{rad}$ were observed. No particular motion discontinuity accumulated over the 1993-2002 period was higher than $8 \mathrm{~mm}$, and only one steady tilting is noted at a rate of $0.16 \mu \mathrm{rad} / \mathrm{yr}$ for a $2.8-\mathrm{km}$-long segment (see Fig. 2 for examples on the 1995-2001 period).

Some places showed important height changes almost every year, but with frequent sense reversals and a negligible resultant displacement after 9 years. Not being geodetic artefacts, these oscillations point to the influence of near-surface factors of displacement. However, the non-random patterns of motion and their independence of the type of monumentation prevent associating them directly with monument instability as often suggested [23-25].

\section{Near-surface origin of ground motion}

In the absence of groundwater and soil moisture data, I used rainfall data to assess the possible linkages between ground motion and water content variations in the soil and subsoil. Daily values from either of two sites located within or very close to the levelled network and fairly representing the two contrasted topoclimatological contexts prevailing in the area were assigned to every individual levelling section, and several cumulative functions convolving rainfall on various time lengths were calculated.

Table 2 shows the correlation coefficients computed between height change variations and several short-term rainfall functions (RF) for $12 \mathrm{sec}-$ tions representative of the various morphological/ geological environments present in the study area. Functions of the form:

$$
(\mathrm{RF})_{i}=\sum_{k=i-p}^{i} r_{k} e^{\left(t_{k}-t_{t}\right) / \tau}
$$

(with $r_{k}=$ daily rainfall; $\tau=$ time constant and $p=$ model order) involve rainfall of the last 1 day to 6 weeks before the measurements and show no significant correlation with ground motion at the 95\% confidence level. Only weak correlations occur sparsely between particular sections and RFs. Instead, the yearly mean section height change variation over the whole network has been demonstrated to strongly depend on the varying amounts of precipitation fallen during the 6 months preceding each survey [22], i.e. precipitation of winter and early spring. In this case, the most efficient rainfall function simply is:

$f=\sum_{m=-3}^{-1} \Delta P_{m(t, t-1)}+0.5 \sum_{m=-6}^{-4} \Delta P_{\prime}^{\prime} m(t, t-1)$

where $\Delta P_{m(t, t-1)}=$ difference in monthly precipitation between years $t$ and ( $t-1)$ (Fig. 3).

Not only does this suggest that the short-term response to wetting and drying of the shallow soil

Table 2

Pearson's correlation coefficients between ground motion and various short-term rainfall functions of the form $(\mathrm{RF})_{i}=\sum_{k=i-p}^{i} \mathrm{r}_{k} e^{\left(t_{k}-t_{t}\right) / \tau}$ for 12 representative sections $\left(r_{k}=\right.$ daily rainfall; $\tau=$ time constant; $p=$ model order $)$

\begin{tabular}{|c|c|c|c|c|c|c|c|c|c|c|c|c|}
\hline \multirow[t]{2}{*}{$\mathrm{RF}$} & \multicolumn{12}{|c|}{ Section } \\
\hline & $23-24$ & $17-18$ & $12-13$ & $10-11$ & $8-9$ & $5-6$ & $26-27$ & $32-33$ & $37-38$ & $42-43$ & $50-51$ & $45-46$ \\
\hline $\operatorname{RF} 1(p=1, \tau=4)$ & 0.30 & -0.63 & 0.57 & -0.22 & -0.40 & 0.01 & 0.19 & -0.68 & 0.08 & -0.34 & -0.20 & 0.03 \\
\hline $\operatorname{RF} 2(p=7, \tau=4)$ & 0.38 & -0.56 & 0.56 & -0.18 & -0.54 & -0.07 & 0.10 & -0.55 & -0.18 & -0.19 & -0.67 & -0.53 \\
\hline $\operatorname{RF} 3(p=14, \tau=7)$ & 0.42 & -0.46 & 0.54 & -0.14 & -0.56 & -0.06 & 0.25 & -0.67 & -0.04 & 0.00 & -0.66 & -0.45 \\
\hline $\mathrm{RF} 4(p=28, \tau=14)$ & 0.25 & -0.56 & 0.60 & -0.29 & -0.67 & 0.10 & 0.24 & -0.69 & 0.36 & -0.03 & 0.23 & -0.53 \\
\hline $\operatorname{RF} 5(p=42, \tau=14)$ & 0.25 & -0.56 & 0.58 & -0.31 & -0.70 & 0.14 & 0.30 & -0.74 & 0.36 & -0.05 & 0.40 & -0.50 \\
\hline
\end{tabular}

Fig. 3 plots the average behaviour of all sections of the network against variations in winter rainfall, represented by one single value per campaign. By contrast, in the short-term analysis, individual RF values are assigned to every section, making nonsensical to average the information on the whole network since each section responds in an unique way to precipitation. Therefore, the temporal relationships with rainfall which I present here involve individual sections.

The figures in bold are significant at the $90 \%$ level $(n=8)$. 


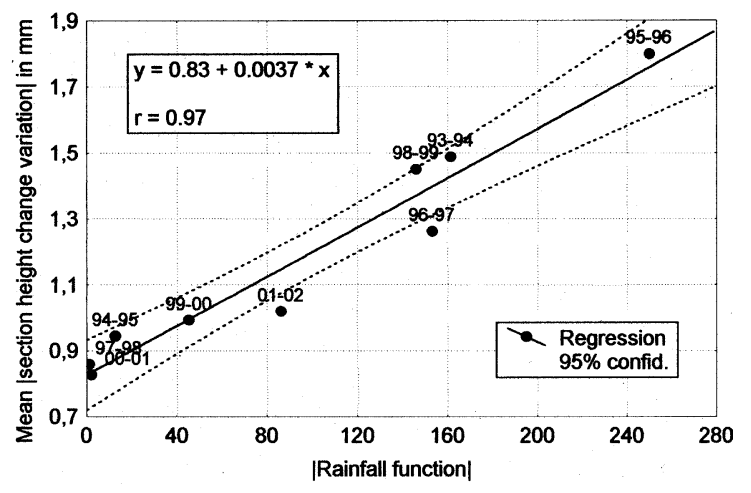

Fig. 3. Correlation plot of yearly mean section height change variation versus rainfall function. Both variables are taken in absolute value because consolidation-dependent benchmark motions are assumed to be free and section height change variation may thus have indifferently a plus or minus sign. The rainfall function $f=\Sigma_{m=-3}^{-1} \Delta P_{m(t, t-1)}+0.5 \Sigma_{m=-6}^{-4} \Delta P_{m(t, t-1)}$ involves the monthly precipitation $P_{m}$ of the last 6 months (including winter rainfall) before the surveys at time $t$ and $t-1$. This particular, highly correlated function describes the precipitation conditions determining the spring drying off and consolidation of the subsoil, dependent on the nature of the substratum in the study area. Adequate functions might be different in the case of a Palaeozoic bedrock or a thick Tertiary sand cover and are most easily determined empirically.

plays a subordinate role in determining vertical ground motion, but also the nature of the parameter I used $-|\Delta H|_{m}$, the yearly mean section height change variation in absolute value - shows that ground displacements are sensitive to spatial variations of the causal factor at the $\mathrm{km}$-scale. It seems impossible that loading by groundwater be responsible for such a highly differential influence, all the more as the recorded motion amplitude would imply unrealistic groundwater table varia- tions. A better candidate for explaining the link between ground motion and the amount of winter rainfall certainly is the variable spring drying off and subsequent consolidation of the material of the vadose zone at the time of the surveys [26]. In this case, the spatial variability of ground motion is accounted for by the variable nature and thickness of colluvium, cover sediments and weathered bedrock.

Moreover, Table 3 shows that all geomorphological subareas covered by the levelling network display similar strong links between yearly mean section height change variation and the winter rainfall function. In particular, the displacements recorded for the most mobile individual sections located in the Vesdre alluvial plain are also markedly dependent on drying off. As the location of these larger vertical displacements is in several cases determined by the presence of faults, the latter's passive influence may easily be confused with true tectonic activity (Fig. 4).

Complementing the site monitoring and modelling of the same relation by several authors [2629], I show here that ground movements depending on the degree of drying off and consolidation of the subsoil generally display sharp local/regional-scale gradients and may reach one or two centimetres in amplitude. The sense reversals of ground motion which are frequently observed in the case of several successive surveys result from the same cause. The obvious consequence is that, in the mm-to-cm amplitude range, very few of the vertical movements identified by comparing levelling surveys are not contaminated by near-surface influences and may indeed reveal a true tectonic activity. This conclusion casts heavy doubts on

Table 3

Pearson's correlation coefficients between yearly mean section height change variation and the ' 6 months' rainfall function for subareas corresponding to different morphological/geological settings

\begin{tabular}{ll}
\hline & $\rho$ \\
\hline Whole network & 0.97 \\
Most mobile sections 5-6+8-9 (limiting a 'block' in the Vesdre alluvial plain) & 0.82 \\
Network without sections 5-6 and 8-9 & 0.95 \\
Alluvial plain of the Vesdre River & 0.85 \\
Network without the Vesdre alluvial plain & 0.89 \\
\hline
\end{tabular}

All subareas display similar strong links between yearly mean section height change variation and the winter rainfall RF. The slightly lower $\rho$ values for the sections in the $\sim 5$-m-thick alluvial plain of the Vesdre River result from a higher influence of short-term precipitation in the soils of this sector. 


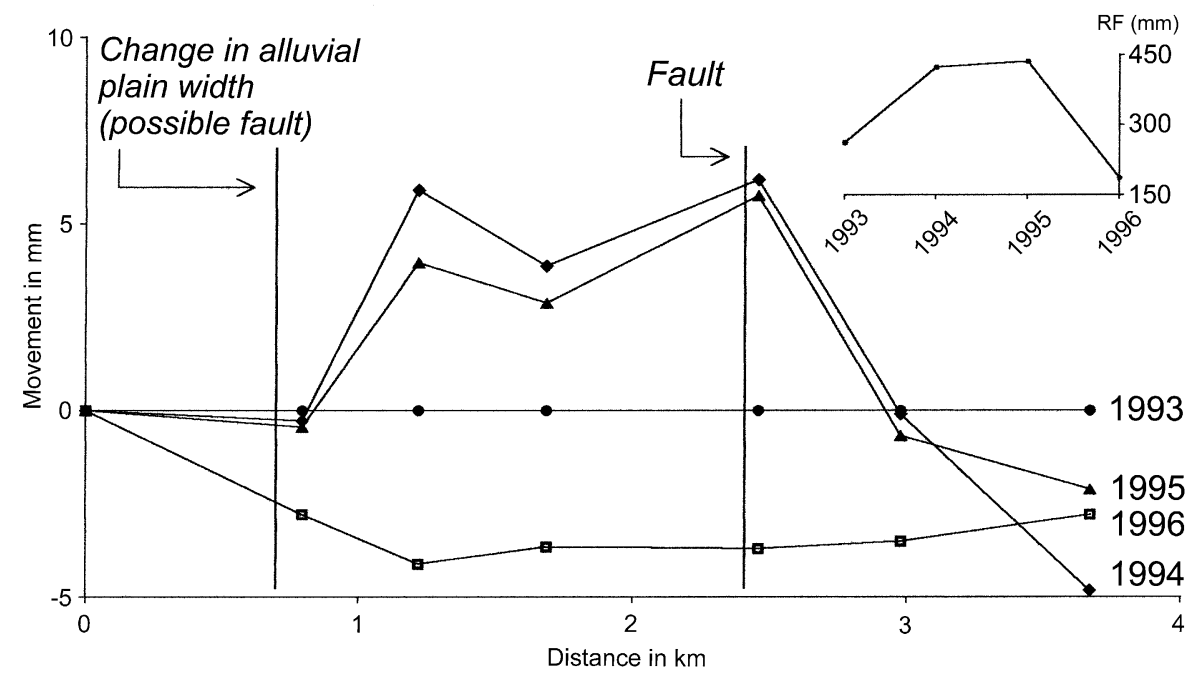

Fig. 4. Vertical motion recorded for the most mobile sections in the Vesdre valley from 1993 to 1996 (location: see Fig. 1). The successive curves illustrate the dependence of the ground motion on the amount of rainfall during the 6 months preceding each survey and the subsequent drying off of the subsoil. Some of the highest movements take place on faults. The rainfall function curve $f=\Sigma_{m=-3}^{-1} P_{m}+0.5 \Sigma_{m=-6}^{-4} P_{m}$ for the $1993-1996$ period is displayed in the inset.

every interpretation in terms of active tectonics of vertical movements inferred from national or special levelling comparisons based on only two or three surveys, which is the usual case $[1-7,12]$.

\section{Vertical motions of tectonic origin and geodetic motion rate}

Unless the very improbable prerequisite of similar drying off conditions during the compared surveys is satisfied for every section, establishing the tectonic character of geodetically inferred small-scale ground motion patterns in intraplate areas requires both the spatial and temporal redundancy of their signature, i.e. confirmation of the latter by several consistent sections and surveys respectively on each spatial and temporal side of the recorded change (Fig. 5).

In this study, such a requirement was met only by four ground movements (Fig. 1), two of which occurred at two neighbouring points of the same fault zone between the 1998 and 1999 surveys and a third one, which corresponded to the more or less steady arching of the Ardenne massif (Fig. 6). In contrast with an observed maximum raw displacement of $16 \mathrm{~mm}$ in yearly survey compari- sons, the recorded total amplitudes ranging between 2.5 and $4 \mathrm{~mm}$ for the ascertained fault motions during the 1993-2002 period already reduces the estimated movement rates to more rea-

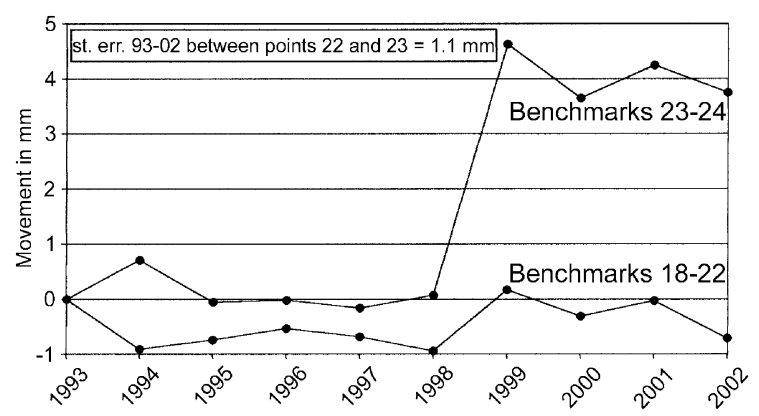

Fig. 5. Detection of a small vertical motion whose interpretation as a fault creep event is supported by the analysis of successive surveys (location: see Fig. 1). The spatial redundancy, preventing to misinterpret monument instability, is provided by comparing homogeneous segments comprised of several sections on each side of the discontinuity (the rms of individual benchmark motions with respect to the mean of each segment are of 0.6 and $0.3 \mathrm{~mm}$ for the $18-22$ and $23-$ 24 segments, respectively). The temporal redundancy, with six surveys displaying the same 'initial' relative position of the segments and four later surveys consistently showing the same change, which occurred in 1998-1999, makes sure that the recorded motion is not a drying-off-dependent oscillatory ground displacement, but rather a tectonic fault movement. 

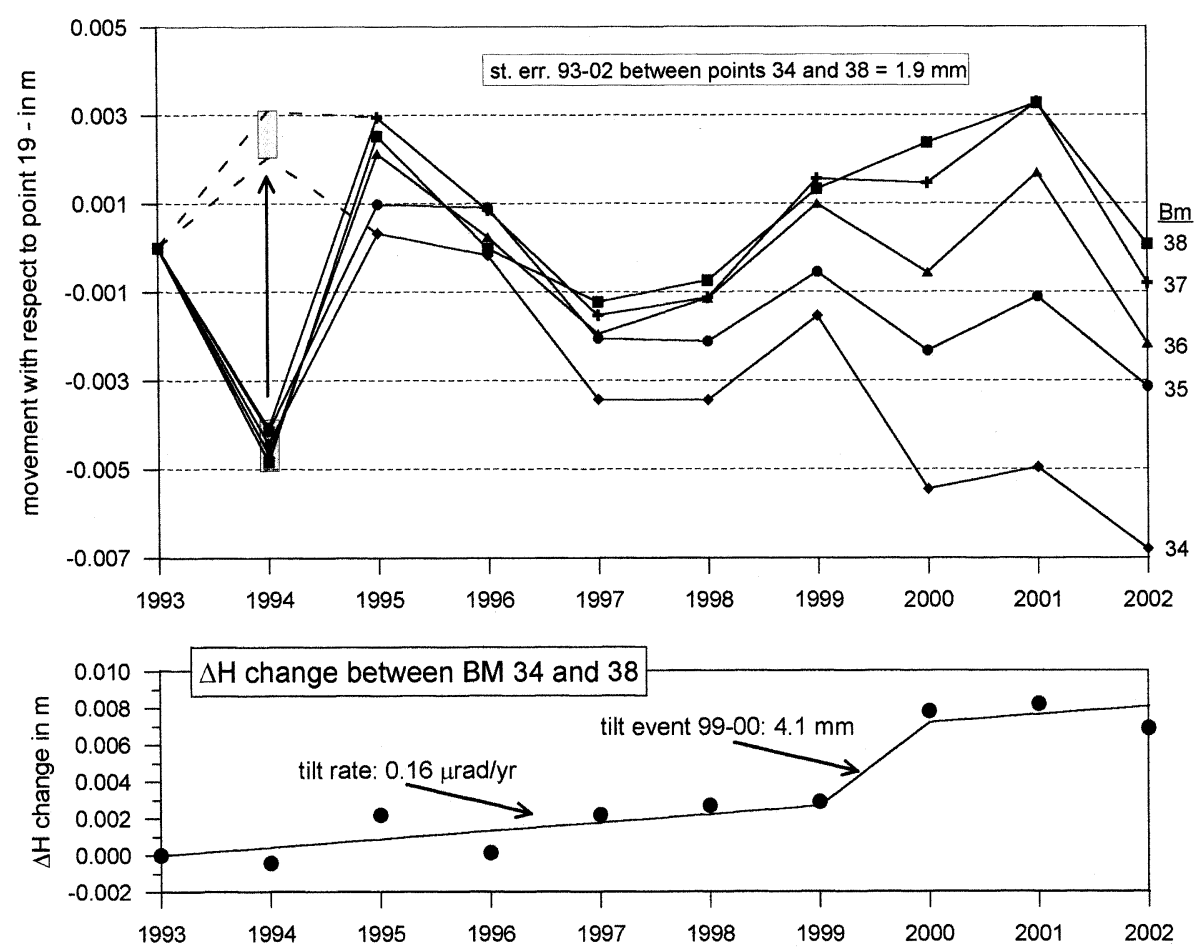

Fig. 6. Tilting of a $\sim 2.8$-km-long segment located between benchmarks 34 and 38 across the N slope of the Stavelot massif (location: see Fig. 1). Each curve corresponds to the 1993-2002 evolution of one benchmark (Bm) of the 34-38 segment. The rectangle displaced by an arrow describes the removal of a systematic error in the 1994 survey. Beside a possible motion of the whole segment with respect to the reference benchmark 19 situated $10 \mathrm{~km}$ apart, the fan-shaped widening between the curves of points 34 and 38 evidences its tilting. A marked tilt episode occurred between the 1999 and 2000 surveys. The bottom diagram describes for the 34-38 segment the superposition of this $\sim 4.1-\mathrm{mm}$ tilt event and a linear fit to the $\Delta H$ changes yielding a decadal tilt rate of $0.16 \mu \mathrm{rad} / \mathrm{yr}$ (i.e. a flexure amplification rate of $0.44 \mathrm{~mm} / \mathrm{yr}$ ).

sonable values of $0.28-0.44 \mathrm{~mm} / \mathrm{yr}$. However, we also have to account for the limited number of active faults present in the study area that actually moved during that time interval. Neotectonic data and the regional diffuse seismicity indicate that potentially moving faults cross the levelling lines in about 15 different points (Fig. 1). If we assume that the probability of catching a ground motion during the 1993-2002 period was the same for all these points (which is unrealistic, but the approximation is authorised by the fact that the actually recorded displacements did not all appear on the most active faults of the area), we are justified in further dividing the above rates by 5 (in inverse proportion to the number of hits, i.e. 3 of 15 faults displaced). This yields final estimates of present-day rate of fault motion in the order of $0.06-0.09 \mathrm{~mm} / \mathrm{yr}$, averaging the activity of all ac- tive faults crossed by the levelling lines. This is fairly consistent with estimated upper Pleistocene rates of $\sim 0.05 \mathrm{~mm} / \mathrm{yr}$ for several faults in the study area [30]. Although the respective degrees of activity are probably somewhat different, the agreement is also excellent with values of $0.07-$ $0.10 \mathrm{~mm} / \mathrm{yr}$ given for Pleistocene rates of nearby (more active) border faults of the Lower Rhine Embayment (Table 1).

The comparison between geological and geodetic estimates of the rate of regional motion is also satisfying. Based on river terrace reconstruction, common belief is that the regional doming centred on NE Ardenne and Eifel proceeded at a mean rate of $0.25 \mathrm{~mm} / \mathrm{yr}$ during the last million years $[16,18]$, and the area covered by the $S$ part of our levelling network might have undergone even higher uplift [31]. Our levelling data record 
the subcontinuous tilting of a $2.8-\mathrm{km}$-wide stretch which localises a flexure developing at a mean rate of $\sim 0.44 \mathrm{~mm} / \mathrm{yr}$ (i.e. a tilt rate of $0.16 \mu \mathrm{rad} / \mathrm{yr}$ ) along the flank of the uplifting massif (Fig. 6). Between 1999 and 2000, a particular tilt event of $4 \mathrm{~mm}$ amplitude superposed on this trend. This is much more consistent with geological data than previous geodetic estimates, e.g. uplift $>1.6 \mathrm{~mm} /$ yr for the Eifel with respect to reference points in other parts of the uplifting Rhenish shield [1] or $0.8 \mathrm{~mm} / \mathrm{yr}$ for the Maastricht area, outside the region of main uplift $[12,32]$. Overestimates of regional relative motion may again have resulted partly from the use of only two or three national height surveys, where adjacent loops have been frequently measured at quite different times, and thus under highly variable subsoil moisture conditions. Due to this problem, the tectonic interpretation of levelling comparisons in whatever geodynamical setting is also certainly questionable when they deal with displacements at the cm-level on the basis of too few measurement epochs.

\section{Nature of the observed fault motions}

Our data also provide an insight into one way that moderately active intraplate normal faults use to accommodate tectonic strain aseismically. The fault displacements we recorded occurred every time across 5-to-10-km-long fault segments during a single year. Such motion events of a few $\mathrm{mm}$ amplitude and probably short duration separated by many year-long periods of stillness (at least 5 years in this study) are similar in nature to fault creep, extensively described, e.g. along some segments of the San Andreas fault [33,34], but with a reduced frequency adapted to slower stress accumulation and consequently smaller deformation rates. It is of particular interest that such a transient motion also occurred in the case of a flexure, superposed on a smoother long-term tilting.

A typical 3-mm creep event should occur every 50 years on average on a fault with a motion rate of $0.06 \mathrm{~mm} / \mathrm{yr}$. In other words, the creeping equivalent of a $0.5 \mathrm{~m}$ coseismic surface rupture with a return period of $5 \mathrm{kyr}$ [9] would imply a 3-mm displacement every 30 years in average. This obviously renders elusive the geodetic monitoring of potentially seismogenic faults for earthquake-hazard-related purposes in zones of moderate seismicity, especially in the short and middle terms. However, I provide here some observations of how intraplate normal faults can behave aseismically and future investigations should concentrate on whether recording such aseismic slip events in intraplate settings may give any indication regarding the possible seismogenic character of a fault.

\section{Acknowledgements}

I thank A. Collignon and his team of the Office for Topography and Cartography, Equipment and Transportation Department, Walloon Region, Belgium, who carried out the high precision surveys with a remarkable efficiency. The constructive reviews of M. Kasser and J. Savage contributed significantly to the improvement of the original manuscript.[ $\boldsymbol{V C}$ ]

\section{References}

[1] H. Mälzer, G. Hein, K. Zippelt, Height changes in the Rhenish Massif. Determination and analysis, in: $\mathrm{K}$. Fuchs, K. von Gehlen, H. Mälzer, H. Murawski, A. Semmel (Eds.), Plateau Uplift: The Rhenish Shield. A Case History, Springer, Berlin, 1983, pp. 164-176.

[2] C. Liaghat, T. Villemin, F. Jouanne, Déformation verticale actuelle dans la partie sud du fossé d'Alsace (France), C.R. Acad. Sci. Paris, Earth Planet. Sci. 327 (1998) 55-60.

[3] Y. Isachsen, Contemporary doming of the Adirondack Mountains further evidence from relevelling, Tectonophysics 71 (1981) 95-96.

[4] N. Lenôtre, P. Thierry, R. Blanchin, G. Brochard, Current vertical movement demonstrated by comparative levelling in Brittany (northwestern France), Tectonophysics 301 (1999) 333-344.

[5] J. Gimenez, E. Surinach, J. Fleta, X. Goula, Recent vertical movements from high-precision leveling data in northeast Spain, Tectonophysics 263 (1996) 149-161.

[6] A. Demoulin, A. Pissart, K. Zippelt, Neotectonic activity in and around the southwestern Rhenish shield (West Germany) Indications of a levelling comparison, Tectonophysics 249 (1995) 203-216.

[7] J. Fourniguet, Géodynamique actuelle dans le nord et le nord-est de la France, BRGM, Mém. 127 (1987), Orléans, $160 \mathrm{pp}$. 
[8] A. Nicol, J. Walsh, J. Watterson, J. Underhill, Displacement rates of normal faults, Nature 390 (1997) 157-159.

[9] T. Camelbeeck, M. Meghraoui, Geological and geophysical evidence for large palaeo-earthquakes with surface faulting in the Roer Graben (northwest Europe), Geophys. J. Int. 132 (1998) 347-362.

[10] J. Pederson, K. Karlstrom, W. Sharp, W. McIntosh, Differential incision of the Grand Canyon related to Quaternary faulting. Constraints from U-series and Ar/Ar dating, Geology 30 (2002) 739-742.

[11] M. Meghraoui, B. Delouis, M. Ferry, D. Giardini, P. Huggenberger, I. Spottke, M. Granet, Active normal faulting in the Upper Rhine Graben and paleoseismic identification of the 1356 Basel earthquake, Science 293 (2001) 2070-2073.

[12] H. Kooi, P. Johnston, K. Lambeck, C. Smither, R. Molendijk, Geological causes of recent $(\sim 100 \mathrm{yr})$ vertical land movement in The Netherlands, Tectonophysics 299 (1998) 297-316.

[13] T. Gardner, D. Jorgensen, C. Shuman, C. Lemieux, Geomorphic and tectonic process rates Effects of measured time interval, Geology 15 (1987) 259-261.

[14] A. Friedrich, B. Wernicke, N. Niemi, R. Bennett, J. Davis, Comparison of geodetic and geologic data from the Wasatch region, Utah, and implications for the spectral character of Earth deformation at periods of 10 to 10 million years, J. Geophys. Res. 108 (2003) 2199, doi: 10.1029/2001JB000682.

[15] J. Ritter, M. Jordan, U. Christensen, U. Achauer, A mantle plume below the Eifel volcanic fields, Germany, Earth Planet. Sci. Lett. 186 (2001) 7-14.

[16] W. Meyer, J. Stets, Junge Tektonik im Rheinischen Schiefergebirge und ihre Quantifizierung, Z. Dtsch. Geol. Gesch. 149 (1998) 359-379.

[17] Y. Quinif, Karst et evolution des rivières: le cas de l'Ardenne, Speleochronos HS (1998) 145-148.

[18] R. Van Balen, R. Houtgast, F. Van der Wateren, J. Vandenberghe, P. Bogaart, Sediment budget and tectonic evolution of the Meuse catchment in the Ardennes and the Roer Valley Rift System, Global Planet. Change 27 (2000) 113-129.

[19] L. Ahorner, Historical seismicity and present-day microearthquake activity of the Rhenish massif, Central Europe, in: K. Fuchs, K. von Gehlen, H. Mälzer, H. Murawski, A. Semmel (Eds.), Plateau Uplift. The Rhenish Shield, A Case History, Springer, Berlin, 1983, pp. 198221.

[20] T. Camelbeeck, K. Vanneste, P. Alexandre, L'Europe occidentale n'est pas à l'abri d'un grand tremblement de terre, Ciel Terre 115 (1999) 13-23.

[21] R. Stein, Discrimination of tectonic displacement from slope-dependent errors in geodetic levelling from southern California, 1953-1979, in: Earthquake Prediction: An International Review, Maurice Ewing Ser., vol. 4, AGU, Washington, DC, 1981, pp. 441-456.

[22] A. Demoulin, A. Collignon, Reply to comment by T. Camelbeeck et al. on 'Nature of the recent vertical ground movements inferred from high-precision leveling data in an intraplate setting: NE Ardenne, Belgium', J. Geophys. Res. 107 (2002) 2282, doi: 10.1029/2002JB001837.

[23] A. Sylvester, Leveling precision and bench mark motions, Piñon Flat Observatory, California, J. Geophys. Res. 89 (1984) 7949-7956.

[24] F. Wyatt, Displacement of surface monuments: Vertical motion, J. Geophys. Res. 94 (1989) 1655-1664.

[25] H. Johnson, D. Agnew, Monument motion and measurements of crustal velocities, Geophys. Res. Lett. 22 (1995) 2905-2908.

[26] S. Zerbini, B. Richter, M. Negusini, C. Romagnoli, D. Simon, F. Domenichini, W. Schwahn, Height and gravity variations by continuous GPS, gravity and environmental parameter observations in the southern Po Plain, near Bologna, Italy, Earth Planet. Sci. Lett. 192 (2001) 267 279.

[27] G. DalMoro, M. Zadro, Subsurface deformations induced by rainfall and atmospheric pressure: Tilt/strain measurements in the NE-Italy seismic area, Earth Planet. Sci. Lett. 164 (1998) 193-203.

[28] C. Braitenberg, Estimating the hydrologic induced signal in geodetic measurements with predictive filtering methods, Geophys. Res. Lett. 26 (1999) 775-778.

[29] H. Kümpel, K. Lehmann, M. Fabian, G. Mentes, Point stability at shallow depths: Experience from tilt measurements in the Lower Rhine Embayment, Germany, and implications for high-resolution GPS and gravity recordings, Geophys. J. Int. 146 (2001) 699-713.

[30] A. Demoulin, Quaternary tectonics in the northern Ardennes (Belgium), Tectonophysics 163 (1989) 315-321.

[31] F. Gullentops, Uplift of the Hautes Fagnes, Aardk. Meded. 8 (1997) 95-98.

[32] M. van den Berg, W. Groenewoud, G. Lorenz, P. Lubbers, D. Brus, S. Kroonenberg, Patterns and velocities of recent crustal movements in the Dutch part of the Roer Valley rift system, Geol. Mijnb. 73 (1994) 157-168.

[33] C. Thurber, Creep events preceding small to moderate earthquakes on the San Andreas fault, Nature 380 (1996) 425-428.

[34] E. Roeloffs, Creep rate changes at Parkfield, California 1966-1999: Seasonal, precipitation induced, and tectonic, J. Geophys. Res. 106 (2001) 16525-16547.

[35] M. van den Berg, Neotectonics of the Roer Valley rift system: Style and rate of crustal deformation inferred from syntectonic sedimentation, Geol. Mijnb. 73 (1994) $143-156$.

[36] B. Hallegouet, B. van Vliet, Les oscillations climatiques entre 125,000 et le dernier glaciaire, d'après l'étude des formations marines, dunaire et périglaciaires de la côte des Abers (Finistère), Bull. Ass. Fr. Etud. Quat. 1/2 (1986) 127-138.

[37] A. Pissart, P. Lambot, Les mouvements actuels du sol en Belgique; comparaison de deux nivellements IGN (19461948 et 1976-1980), Ann. Soc. Géol. Belg. 112 (1989) 495 504.

[38] A. Demoulin, L'Ardenne bouge toujours. Néotectonique 
du massif ardennais, in: A. Demoulin (Ed.), L’Ardenne. Essai de géographie physique, Dept. phys. Geogr. Quat., Univ. Liège, 1995, pp. 110-135.

[39] M. Meghraoui, T. Camelbeeck, K. Vanneste, M. Brondeel, D. Jongmans, Active faulting and paleoseismology along the Bree fault, lower Rhine graben, Belgium, J. Geophys. Res. 105 (2000) 13809-13841.
[40] J. Gimenez, E. Surinach, X. Goula, Quantification of vertical movements in the eastern Betics (Spain) by comparing levelling data, Tectonophysics 317 (2000) 237-258.

[41] P. Silva, J. Goy, C. Zazo, T. Bardaji, Fault-generated mountain fronts in southeast Spain geomorphologic assessment of tectonic and seismic activity, Geomorphology 50 (2003) 203-225. 